\title{
Epstein-Barr Virus DNA Positive
}

National Cancer Institute

\section{Source}

National Cancer Institute. Epstein-Barr Virus DNA Positive. NCI Thesaurus. Code C141397.

An indication that Epstein-Barr virus DNA has been detected in a sample. 